\title{
BAGAIMANA PEMBELAJARAN BAHASA DAN APRESIASI SASTRA INDONESIA DENGAN MENGGUNAKAN MODEL YANG KREATIF DAN INOVATIF?
}

\author{
Nia Oktaviani \\ niaoktaviani525@gmail.com
}

Dalam dunia pendidikan guru harus menciptakan model pembelajaran yang kreatif dan inovatif, agar peserta didik semangat dalam proses pembelajaran. Dengan pembelajaran yang kreatif dan inovatif akan mencetak generasi yang cerdas, berwawasan serta berilmu pengetahuan yang tinggi. Pada saat ini berbagai macam model dan inovasi yang digunakan guru dalam pembelajaran bahasa Indonesia. Dalam pembelajaran bahasa Indonesia sebagai guru menghadapi masalah dan proses pembelajaran, terutama pada aspek koognitif, yaitu kurangnya pemahaman guru dalam mengajar (Sukma, 2019).Salah satu mata pelajaran yang saat ini banyak mendapat sorotan adalah bahasa Indonesia. Mata pelajaran bahasa Indonesia yang bersungguh-sungguh untuk berhasil menjadi ujian nasional tersebut sehingga sekolah memberikan prioritas lebih terhadap mata pelajaran bahasa Indonesia. Untuk itu guru harus menggunakan model pembelajaran yang menarik dalam pembelajaran bahasa Indonesia. Selain itu, penggunaaan berbagai model pembelajaran dapat menambah pemaham siswa dalam pembelajaran, (Sukma, 2018).

Menurut Sukma (2016)Pembelajaran sastra merupakan pembelajaran yang menarik. Di dalam karya sastra terdapat nilai-nilai kehidupan, baik nilai-nilai spitural, moral, sosial dan sebagainya. Pembelajaran sastra ditujukan untuk meningkatkan kemampuan peserta didik dalam menikmati, menghayati, dan memahami karya sestra serta mengambil hikmah dari nilai-nilai luhur yang terselubung di dalamnya. Menurut Silfia, et al (2018) karya sastra merupakan suatu bentuk dan hasil pekerjaan seni yang objeknya adalah manusia dan kehidupannya dengan menggunakan bahasa sebagai medianya. Karya sastra berbentuk kreativitas dalam bahasa yang indah berisi sederetan pengalaman batin dan imajinasi yang berasal dari penghayatan realitas sosial pengarang. Sejalan dengan pendapat Fitri, et al (2012) pada hakikatnya karya sastra merupakan cerminan dari realitas kehidupan manusia. Oleh karena itu, karya sastra selalu menaik perhatian pembacanya. Membaca berbagai karya sastra akan membuat kita larut ke 
dalam alur kisah karya sastra tersebut. Menurut jenisnya, karya sastra terbagi tia, yaitu puisi, prosa, dan drama.masing-masing jenis memiliki kekhasan tersendiri.

Menurut Piliang, et al(2014) kemampuan mengapresiasi karya sastra merupakan sesuatu yang sangat diperlukan baik bagi kehidupan sastra itu sendiri maupun bagi apresiator. Kemampuan apresiasi sastra dan berfikir kreatif penting dalam upaya peningkatan keterampilan bermain drama. Peserta didik yang memiliki kemampuan apresiasi sastra dan berpikir kreatif yang baik maka keterampilan bermain dramanya juga baik. Menurut Amin, et al (2013) kehadiran sastra lisan dalam kehidupan bermasyarakat merupakan cerminan solidaritas dan pengenal identitas yang disampaikan secara lisan dan memiliki tujuan tertentu. Dengan sastra lisan, masyarakat purba atau nenek moyang umat manusia mengekspresikan gejolak jiwa dan renungannya tentang kehidupan. Kekayaan khasanah sastra Nusantara secara garis besar dapat dibagi tiga, yaitu sastra lisan, sastra tulis dan sastra modern.Menurut Ramadhan (2008)pemakaian bahasa dalam pembelajaran dan apresiasi sastra Indonesia tidak dapat dilepaskan dari fungsi bahasa dan kompoen-komponen interaksi yang lain. Keberhasilan pemakaian bahasa sebagai sarana interaksi dengan fungsi tersebut dipengaruhi oleh faktor perilaku tutur dan konteks yang melatarinya. Oleh sebab itu, pemakaian bahasa dapat dipandang sebagai sistem yang di dalamnya melibatkan komponen kebahasaan, pelaku tutur, dan konteks tersebut. Maka dari itu, pembelajaran bahasa dan apresiasi sastra Indonesia haruslah diperhatikan dalam tindak tutur penggunaan bahasa saat berinteraksi.

Menurut Tatalia, et al (2015) model pembelajaran yang kreatif, menarik sekaligus dapat membantu peserta didik dalam berlatih, seperti menulis, serta dapat melatih sisiwa dalam mengembangkan ide-ide dan gagasan yang kreatif dan inovatif, salah satunya ialah menggunakan model pembelajaran kooperatif tipe STAD berbantuan pemetaan pemikiran (mind mapping), hal ini telah diterapkan oleh peniliti, dan hasil penelitiannya kemampuan pemahaman serta menulis peserta didik meningkat. Selain itu model yang kreatif dapat mengembangkan kemampuan sisiwa dalam berbagai aspek keterampilan bahasa, seperti membaca, menulis, menyimak, mendengar, menyaji, dan memirsa. Menurut Fitri, et al (2016) model pembelajaran yang digunakan guru hendaklah model yang dapat meningkatkan kemampuan berpikir kritis, dan inovatif, sehingga pembelajaran berguna bagi dirinya dan lingkungnnya. Dalam pembelajaran bahasa Indonesia guru juga dapat menggunakan model pembelajaran saintifik, dan diterapkan 
dalam kegiatan pelaksanaan pembelajaran dengan memperhatikan sintak-sintak model tersebut. Dalam model saintifik dengan berbagai inovasinya, seperti model saintifik yang di inovasikan dengan media dalam pembelajaran . Dari sintak-sintak saintifik, siswa awalnya mengamati, tayangan berupa video, kemudian siswa bertanya tentang apa yang tidak mereka mengerti, dan informasi yang di dapat mereka kumpulkan kemudian siswa menalar informasi tersebut yang terakhir guru dapat menayangkan video yang kedua atau karya guru beserta dengan format, kemudian siswa disuruh untuk mengisi dan yang terakhir, mengkomunikasikan di depan kelas.

\section{Daftar Rujukan}

Amin, I., Ramadhan, S., \& Ermanto. (2013). Cerita rakyat penamaan desa di Kerinci: kategori dan fungsi sosial teks. Jurnal Bahasa, Sastra, dan Pembelajaran. 1(1) 31-41.

Fitri, N. S. et al. (2012). Resepsi sastra naskah drama Kau Tunggu Siapa Nilo karya Wisran Hadi. Jurnal Pendidikan Bahasa dan Sastra Indonesia. 1(1) 44-51.

Fitri,Y., Rahmadan,S., \& Tamsin, S., C. (2016). Pengaruh model pembelajaran kooperatif tipe think talkwrite berbantuan media gambar terhadap keterampilan menulis karangan argumentasi siswa kelas X SMA Negeri 5 Padang. Jurnal Pendidikan Bahasa dan Sastra Indonesia.5(2) 548-554.

Piliang, W. S. H., Atmazaki, \& Ramadhan, S. (2014). Konstribusi kemampuan apresiasi sastra dan berpikir kreatif terhadap keterampilan bermain drama pada siswa kelas XII IPS SMA Negeri 2 Rengat Kabupaten Indragiri Hul. Jurnal Bahasa, Sastra, dan Pembelajaran. 2(2) 75-87.

Ramadhan, R. (2008). Representasi kesatuan tindak tutur berbahasa Indonesia dalam pembelajaran di kelas (kajian etnografi komnikasi). Jurnal Diksi. 15(2) 120-136.

Silfia, M., Rahmadhan, S., \& Afnita. (2018). Permasalahan sosial dalam novel Di Batas Pelangi karya Achi Tm. Jurnal Diksi. 26(1) 11-17.

Sukma, E. (2016). Pembelajaran sastra yang integratif berbasis kompetensi. Proceeding of International Seminar on Languages and Arts: (ISLA). Atlantis press.

Sukma, E. (2018). Problem in language teaching in elementary school. international conference on languages and arts(ICLA 2018). Atlantis press.

Sukma, E. (2019). Problem in oral language teaching in primary school. Seventh international conference on languages and arts(ICLA 2018). Atlantis press. 
Tatalia, R. G., Ramadhan, S., \& Ermanto. (2015). Pengaruh model pembelajaran kooperatif tipe STAD berbantuan pemetaan pikiran(MIND MAPPING) dengan mempertimbangkan motivasi belajar terhadap kemampuan menulis. Jurnal Bahasa Sastra dan Pembelajaran. 3(1) $36-45$. 